\title{
Janowi Malczewskiemu w dowód serdecznej pamięci i głębokiego uszanowania
}

Nie jest łatwo pisać o drugim człowieku, zwłaszcza wtedy, gdy tak szybko odszedł i gdy znało się go nie od wczoraj, i gdy go się ceniło. Staję więc przed trudnym zadaniem utrwalenia kilku wspomnień i refleksji dotyczących profesora dr. hab. Jana Stanisława Malczewskiego. Zapominanie jest bowiem, niestety, nader powszechną cechą ludzi.

Poznałem Go bliżej w czasie mojej samorządowej służby Rzeszowowi (radny: 1990-1998; prezydent Rzeszowa: 1991-1999). Jedną z pierwszych decyzji Zarządu Miasta, któremu przewodziłem, było doprowadzenie do opracowania i uchwalenia planu zagospodarowania przestrzennego Rzeszowa. Dr Jan Malczewski był członkiem zespołu projektowego tego planu. Odpowiadał za opracowanie jakże ważnych jego elementów, dotyczących ochrony wartości kulturowych. Plan ten miał być (i był do 31 grudnia 2003 r.) fundamentalnym dokumentem porządkującym obszar Rzeszowa oraz całościowo regulującym jego gospodarkę przestrzenną. Tak też się stało. Miejscowy Plan Ogólny Zagospodarowania Przestrzennego Miasta Rzeszowa został uchwalony przez Radę Miasta Rzeszowa 23 czerwca 1992 r. W zapisach tego planu, którego opracowanie wykonał zespół urbanistów i architektów z Miejskiego Biura Planowania Przestrzennego w Rzeszowie, były uwzględnione również uwagi i sugestie dr. Malczewskiego. Dyskusja w komisjach Rady oraz podczas sesji plenarnej toczyła się burzliwie, ale i merytorycznie. Sprawa ładu przestrzennego przecież była, jest i powinna być ogromnie ważna - nie tylko dla współczesnych, ale także dla przyszłych pokoleń. W tym zakresie zawsze byliśmy zgodni.

${ }^{1}$ Dr Mieczysław Janowski, Instytut Socjologii Uniwersytetu Rzeszowskiego, al. T. Rejtana 16C, 35-959 Rzeszów, e-mail: mieczyslaw.janowski@wp.pl 
W roku 1995 na zrębach Miejskiego Biura Planowania utworzyliśmy Biuro Rozwoju Miasta Rzeszowa, które działa do dziś. Oprócz bardzo ważnych zadań bieżących, związanych z przygotowywaniem merytorycznym uchwał Rady Miasta Rzeszowa dotyczących miejscowych planów zagospodarowania przestrzennego, podjęliśmy wówczas prace nad „Raportem o stania miasta” (1997), „Strategią Miasta Rzeszowa” oraz nad „Studium uwarunkowań i kierunków zagospodarowania przestrzennego". W tych analizach i opracowaniach nie brakło również rzeczowego i konkretnego wkładu Jana Malczewskiego. Dyskusje z Nim były wówczas dla mnie znakomitym poszerzeniem mojej wiedzy na tematy urbanistyczne. Czuło się bowiem w Nim nie tylko specjalistę z zakresu planowania przestrzennego, ale i historyka zainteresowanego zabytkami kultury materialnej oraz zabytkami przyrody, a także wrażliwego na kwestie społeczne naukowca wyczulonego na problemy socjologii miasta.

Chciałbym tu przypomnieć tylko kilka z Jego licznych opracowań, które umacniały moje przekonanie o tym, że dr Jan Malczewski, mając ogromną wiedzę, był równocześnie pasjonatem ładu przestrzennego. Te książki i artykuły są mi dobrze znane, a znaczna ich część znajduje się w moich domowych zbiorach. Oto one:

1. J. Malczewski, Dawne plany, mapy $i$ widoki Rzeszowa, Rzeszów 1985;

2. J. Malczewski, Dzieje Rzeszowa do roku 1914, Rzeszów 1985;

3. J. Malczewski, Rzeszów w starej fotografii, obrazach i rysunkach, Rzeszów 1989;

4. J. Malczewski, Obecnie dzielnice Rzeszowa, niegdyś przedmieścia $i$ wsie podmiejskie, Rzeszów 1989;

5. J. Malczewski, Zabytki architektury sakralnej Rzeszowa, Rzeszów 1992;

6. J. Malczewski, Ochrona wartości kulturowych w studium uwarunkowań i kierunków zagospodarowania przestrzennego dla gmin [w:] Szanse i bariery rozwoju gmin, Rzeszów 1997;

7. J. Malczewski, red., Zamek w Rzeszowie, jego otoczenie $i$ właściciele, Rzeszów 1995;

8. T. Budziński, Zamki i pałace Polski południowo-wschodniej, Rzeszów 1998 (autorem tekstu w albumie jest Jan Malczewski);

9. J. Malczewski, Układ komunikacyjny na obszarze węzłowym aglomeracji rzeszowskiej. Stan obecny i potrzeby [w:] Rzeszów w XX-leciu III RP, red. M. Malikowski, Rzeszów 2012, s. 338-345;

10. A. Gieroń, J. Kwiatkowski, Przestrzeń miejska Rzeszowa. Więcej cienia niż blasku. Wywiad z prof. Janem Malczewskim, „Biznes\&Styl” 2013, nr 2; 
11. J. Malczewski, R. Kwolek, Historia i rozwój przestrzenny Rzeszowa od powstania do wspótczesności, „Renowacje i Zabytki” 2015, nr 3;

12. Udział w zespołach autorskich przygotowujących Dzieje Rzeszowa t. 1-3, Rzeszów 1995-2001.

Niech mi będzie wolno zatrzymać się na chwilę nad Dziejami Rzeszowa ${ }^{2}$. Oczywiście, nie mogło w tym dziele braknąc udziału prof. Jana Malczewskiego. Jego autorstwo obejmuje kilka istotnych rozdziałów:

- Zabudowa mieszczańska [w:] Dzieje Rzeszowa, t. I, red. F. Kiryk, Rzeszów 1995, s. 320-341;

- Przestrzeń miejska, jej zagospodarowanie i zabudowa [w:] Dzieje Rzeszowa, t. II, red. F. Kiryk, Rzeszów 1998, s. 13-47;

- Rozbudowa miasta [w:] Dzieje Rzeszowa, t. II, red. F. Kiryk, Rzeszów 1998, s. 229-274.

W tomie III, wydanym w roku 2001, gdy byłem już senatorem, prof. Malczewski miał swój istotny wkład w prace kolegium redakcyjnego, zwłaszcza w zakresie wyboru ilustracji oraz opracowaniu podpisów pod nimi.

Moje bliższe relacje z prof. Malczewskim osłabły nieco w trakcie pełnienia przeze mnie funkcji senatora (1997-2004), a potem posła do Parlamentu Europejskiego (2004-2009). Spotykaliśmy się wówczas okazjonalnie. Wiedziałem, że Jego opinie cenione są przez administrację wojewódzką. Przykładowo, z pełnym zaangażowaniem włączył się w projektowanie sieci drogowej, a zwłaszcza autostrady i dróg szybkiego ruchu na terenie województwa podkarpackiego. Śmiało można stwierdzić, że przyczynił się do tego, że stolica Podkarpacia ma trzy węzły łączące miasto z autostradą A-4. Wspomagał także panią wojewodę Ewę Draus, zainspirowaną również moim stanowiskiem, w pracach przygotowawczych do Międzynarodowej Konferencji „Jedna droga cztery kraje", która odbyła się 27 października 2006 r. na Zamku w Łańcucie. Było to ważne spotkanie o wielkim znaczeniu dla państw Europy Środkowo-Wschodniej. Uczestniczyli w niej Prezydent RP Lech

${ }^{2}$ Decyzję o wydaniu tej oczekiwanej i monumentalnej pracy podejmowałem w roku 1994 wespół z dwoma profesorami historii. Byli nimi: Feliks Kiryk - ówczesny rektor WSP w Krakowie, autor bądź współautor licznych opracowań dotyczących miast Polski południowej i wschodniej, oraz prof. Włodzimierz Bonusiak - ówczesny rektor WSP w Rzeszowie. Ustaliliśmy, że przy wsparciu miasta zostanie wydane kilkutomowe zbiorowe dzieło o dziejach Rzeszowa we wszystkich możliwych aspektach. Dla zachowania maksymalnego obiektywizmu i niezbędnego dystansu w ocenie przyjęliśmy wówczas za datę kończącą prezentowane dzieje miasta rok 1989, jako rok fundamentalnych przemian społeczno-politycznych w Polsce. Tak było do tomu IV; szkoda może, iż tę zasadę naruszono, wydając tom $\mathrm{V}$, sięgający do czasów najświeższych. 
Kaczyński oraz ministrowie odpowiedzialni za kwestie komunikacji drogowej z Polski, Słowacji, Węgier i Litwy. Podpisano wówczas „Deklarację Łańcucką”, w której wybudowanie drogi szybkiego ruchu „Via Carpatia” określono jako europejski cel strategiczny. Szkoda tylko, że potem zostało to odłożone w czasie. Ufam, że po zobowiązaniach podjętych przed dwoma laty ta ważna inwestycja zmaterializuje się i będzie służyć rozwojowi wschodnich obszarów Unii Europejskiej.

Ucieszyłem się też bardzo, gdy prof. Jan Malczewski wziął udział w konferencji, którą zorganizowałem 21 czerwca 2008 r. wraz z panią poseł dr Grażyną Gęsicką „Rzeszów - metropolia w budowie”. Debata dotyczyła metropolitalnych szans i potencjału naszego miasta. Jego profesjonalizm był mi dobrze znany. Wiedziałem także o bliskich relacjach łączących profesora Jana $\mathrm{z}$ wieloma cenionymi przeze mnie architektami i urbanistami, w tym szczególnie z państwem Anną i Wiesławem Pankiewiczami.

Znałem również Jego zaangażowanie w sprawy Przemyśla. Dotyczyło ono zarówno historii miasta nad Sanem, jak i jego teraźniejszości. Świadczył o tym wymownie Jego doktorat „Rozbudowa Przemyśla w okresie porozbiorowym 1772-1914”, broniony w roku 1982 w Instytucie Historii PAN w Warszawie. Dowodziła tego również m.in. praca profesora w przemyskiej Państwowej Wyższej Szkole Wschodnioeuropejskiej powstałej w roku 2001, gdzie w latach 2008-2012 był prorektorem.

Moje osobiste kontakty z Profesorem doznały ożywienia w roku 2011, gdy podjąłem pracę (na części etatu) w Uniwersytecie Rzeszowskim. Byliśmy obaj włączani w projekty związane z konkursami wiedzy o Rzeszowie, organizowanymi przez Instytut Socjologii UR dla młodzieży rzeszowskich szkół średnich.

Podczas dość częstych rozmów przy kawie lub herbacie wyczuwałem Jego ogromne zainteresowanie jakością studiów. Z wielką satysfakcją pokazywał mi prace licencjackie czy magisterskie swoich podopiecznych. Jak wiem z wypowiedzi moich studentów, którzy mieli z Nim zajęcia lub których prac był promotorem, Profesor cieszył się ogromnym autorytetem i uznaniem młodzieży akademickiej. Był wymagający, ale bardzo życzliwy i solidny.

Pamiętam, że kiedyś około 6 grudnia otrzymaliśmy w upominku maleńkie czekoladowe mikołajki. Delektując się smakiem czekolady i popijając gorącą herbatę, sięgnęliśmy w rozmowie do postaci Świętego Mikołaja z Miry, który uchodzi za dobrodzieja i szczególnie skutecznego opiekuna. - Czy wiesz, że Święty Mikołaj jest także patronem żeglarzy? - zapytał mnie Jan (byliśmy już wtedy po imieniu). Coś tam wiedziałem o Wilhelmie Zdobywcy, który w XI wieku został uratowany z wielkiego 
sztormu dzięki wstawiennictwu Świętego. Wtedy też rozwiązał się worek z pasją profesora, jaką było żeglarstwo. Żeglarze z naszego regionu pamiętają Go z rejsów po Bałtyku, wodach Skandynawii, w rejonie Spitsbergenu oraz Islandii, a także po Morzu Śródziemnym i wielu innych akwenach, w tym również po Zalewie Solińskim.

$\mathrm{Z}$ bólem wspominał dramatyczne wydarzenia związane $\mathrm{z}$ jachtem „Rzeszowiak”. Pierwsze z nich nosi datę 10 sierpnia 2005 r. Doszło wtedy do tragicznego wypadku, gdy w odległości ok 40 mil morskich od Helu podczas sztormu jacht stracił sterowność. Zginął wówczas kapitan Stanisław Mytych (mój przyjaciel z Politechniki Rzeszowskiej). Drugie z tych wydarzeń nastąpiło we wrześniu 2012 r., kiedy to podczas fatalnej pogody w pobliżu Wysp Owczych zginął sternik Lech Machniak.

Naturalnie podczas naszych spotkań nadal omawialiśmy kwestie dotyczące problematyki zagospodarowania przestrzennego. Profesor bardzo wyraziście odniósł się do tych spraw w kontekście rzeszowskim w wywiadzie opublikowanym w lutowym numerze miesięcznika „Biznes\&Styl” z 2013 r. Tytuł: Przestrzeń miejska Rzeszowa. Więcej cienia niż blasku mówi sam za siebie.

Zapamiętałem Go jako człowieka, który swoje kompetencje i wiedzę łączył z przyjaznym stosunkiem do ludzi. Umiał trafnie oceniać sytuację i być wymagającym, ale najpierw wobec siebie. Potrafił się cieszyć radością innych i być wyrozumiałym wobec ich potknięć. Tchnęła od Niego szlachetność.

Trudno jest żegnać kogoś, kto jeszcze mógł być z nami. Trudno, bo naszą miarą mierząc, tak dużo mógł jeszcze zrobić, powiedzieć, napisać, a my..., my po prostu nie zdążyliśmy. Może zatem warto wsłuchać się w przynaglające słowa poety, księdza Jana Twardowskiego:

\footnotetext{
Śpieszmy się kochać ludzi tak szybko odchodzą

I ci co nie odchodzą nie zawsze powrócą

I nigdy nie wiadomo mówiąc o miłości

Czy pierwsza jest ostatnią

Czy ostatnia pierwszą.
}

W sposób szczególny odnosi się do profesora Jana Malczewskiego myśl z „Pieśni” Horacego: „Non omnis moriar - nie wszystek umrę”. Tak, Profesorze - będziesz żył w swoich dziełach oraz w naszych sercach.

W Ewangelii Świętego Jana czytamy tchnące nadzieją słowa Chrystusa: „W domu Ojca mego jest mieszkań wiele [J 14,2]”. Jestem przekonany, że Ty, Drogi Janie, już znalazłeś swoje miejsce w niebiańskiej przestrzeni. 